Hussein M. Taqi Al-Najjar

Assistant Professor University of Baghdad College of Engineering Department of Energy Engineering

Akram W. Ezzat

Professor

University of Baghdad

College of Engineering

Department of Mechanical Engineering

\title{
Thermal-hydraulic Hot-Spot Analysis of IRT-5000 Nuclear Research Reactor: Comparative Safety Evaluation
}

A detailed methodology is presented in this paper for the calculation of nucleate boiling safety margin (NBSM) in nuclear research reactors using a temperature function with three different thermal-hydraulic hot-spot analyses: nominal, cumulative and statistical for normal operating condition and coolant flow variation. A computer simulation program is developed for applying the methodology to the IRT-5000 reactor based on experimental core data. According to cumulative analysis as the overconservative approach, the NBSM at normal operating condition of thermal power $5 \mathrm{MW}$ and coolant velocity $1.672 \mathrm{~m} / \mathrm{s}$ was $2.3 \%$ with reactor power limit $5.13 \mathrm{MW}$. However, during power or coolant flow trip condition, transient nucleate boiling would occur for short period at reactor shutdown. Of great importance, variation of NBSM with reactor operating condition for the different hot-spot analyses is found to be of strong linear correlation such that one analysis is sufficient to specify the results of the other analyses.

Keywords: IRT-5000 research reactor; Thermal-hydraulic hot-spot; Nucleate boiling safety margin; Cumulative analysis; Statistical analysis; Comparative evaluation.

\section{INTRODUCTION}

Safety analysis in design and operation of nuclear reactors is a vital issue as related to critical phenomena of core burnout, critical heat flux, flow redistribution and nucleate boiling (NB) during normal, transient and accident conditions [1-3]. Safety margins against such phenomena are commonly expressed in terms of heat flux or power function as the ratio of initiating condition for the phenomenon to that of normal operating condition [1,3]. Different thermal-hydraulic hot-spot analyses are usually utilized to specify the corresponding safety margins.

There are mainly three approaches for the hot-spot study which differs in the way of treating the hot-channel uncertainties. The nominal approach assumes zero uncertainties, while cumulative approach considers that all uncertainties occur simultaneously at the hot-spot position. The third approach is statistical where uncertainties are assumed to be normally distributed. In this statistical approach either all uncertainties are treated in same manner, also called fully-statistical $[1,4]$ or some of the uncertainties are assumed to be cumulative or nominal, called semi-statistical [1,2 and 4]. Nominal approach is judged to be under-conservative and, on the other hand, cumulative approach is over-conservative, while statistical approach stands between the two extremes [1].

Among the other critical phenomena, NB is most

Received: October 2018, Accepted: December 2018 Correspondence to: Asst. Prof. Hussein M. Al-Najjar, Energy Engineering Department,

University of Baghdad, Aljadria, Baghdad, Iraq E-mail: hussein.alnajjar@coeng.uobaghdad.edu.iq doi: $10.5937 /$ fmet1901212T

(C) Faculty of Mechanical Engineering, Belgrade. All rights reserved important as it imposes a lower limit on reactor operating power. This is due to that NB would be initiated by less restrictive operating conditions. Furthermore, preventing NB will protect the reactor against the other critical phenomena [5]. Long-time NB shall be avoided as it would produce bad effects on reactor operation such as worst reactivity characteristics, control rod oscillations and reactor instability due to partial loss of water coolant/moderator [5]. In fact, $\mathrm{NB}$ is associated with pool-type and pressurized water reactors.

Thermal-hydraulic modeling and analysis had been performed for: boiling crisis and critical heat flux in vertical water channels [6], wall burnout of rifled tubes in a large steam power plant boiler [7] and air-water critical flow in safety valves of pressurized systems and sudden rupture of pipeline fittings [8].

For nuclear reactors, several research papers and studies have been published on safety margins and power limits against different critical phenomena including NB. Khalil et al. [1] evaluated the safety margins of the 22 MW Egyptian Second Research Reactor (ETRR-2) for the phenomena of critical heat flux, flow redistribution and NB using four hot-spot methods. The calculated safety margins for NB were 2.26, 1.35, 1.75 and 1.49 with nominal, cumulative, statistical and semi-statistical analysis respectively. Chiang [2] studied the thermalhydraulic limits against NB, flow redistribution and critical heat flux for the 6 MW MIT Research Reactor (MITR). It was found that the reactor power safety limit for NB using nominal, cumulative and semi-statistical analysis is $11.1 \mathrm{MW}, 8.36 \mathrm{MW}$ and $9.1 \mathrm{MW}$ respectively. Ardaneh and Zaferanlouei [3] developed a nominal analytical solution for the thermal-hydraulic behavior of 
the 5 MW Tehran Research Reactor (TRR) under the failure of core cooling system for the phenomena of NB, flow instability and burnout. The predicted safety margin against NB was found to be 3.01. Fynan and Ahn [9] proposed a methodology for realistic estimates of the safety margin of nuclear power plants using Gaussian process model for addressing thermal-hydraulic uncertainties in design basis accident analysis.

From the forgoing short review, it can be noticed the need for comparative evaluation that can interrelate the various safety margins, for a given critical phenomenon, by the different thermal-hydraulic hot-spot approaches such as to present the corresponding margins with adequate significance instead of just isolated figures. Such relationship for the NB phenomenon is to be considered in the present paper with much investigation as regard to the former Iraqi IRT-5000 research reactor as a case study.

The present work aims to evaluate the safety margins of the IRT-5000 reactor against NB for two cases: normal operating condition and variation in coolant flow. First, detailed methodology needs to be formulated for NB evaluation using three different thermal-hydraulic hot-spot approaches namely: nominal, cumulative and statistical analysis. In this context, a temperature function for the nucleate boiling safety margin $(N B S M)$ is to be introduced as alternative for the com-monly used heat flux or power function. Then, a computer simulation program is to be developed for the hot-spot calculations based on experimental heat distribution, hot-channel uncertainties and correlations of the reactor. Finally, simulation results of the three hot-spot safety analyses are to be investigated for comparative evaluation to point out the conclusions and findings of the work.

\section{CORE CHARACTERISTICS OF IRT-5000}

IRT-5000 is a pool type light water cooled and moderated research reactor that was built by the former Soviet Union for the favor of Iraq. The reactor went critical in 1967 and started operation at full power of 2 MW in 1968. The reactor was upgraded to $5 \mathrm{MW}$ in 1978 and continued operation till 1991 when it was dismantled after the Gulf War. The reactor was mainly used for radioisotope production and as a neutron source for experimental research in the field of nuclear and solid-state physics and activation analysis.

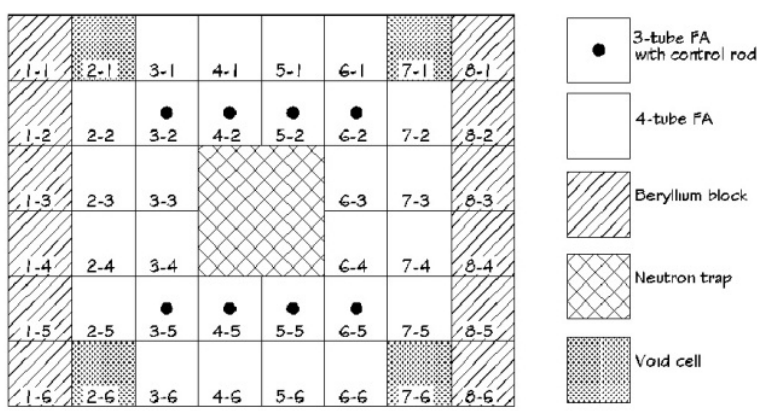

Figure 1. Core configuration of IRT-5000

The reactor core is arranged with 28 fuel assemblies (FAs), see figure 1; each consists of three or four concentric fuel tubes of square cross section with aluminum cladding. A fuel tube is of straight and angular parts. Eight FAs, which enclosed the control rods, are 3-tube of five water channels. The remaining FAs are 4-tube of six water channels, see figure 2. Heat flux and coolant flow characteristics of the core are specified in the following subsections.

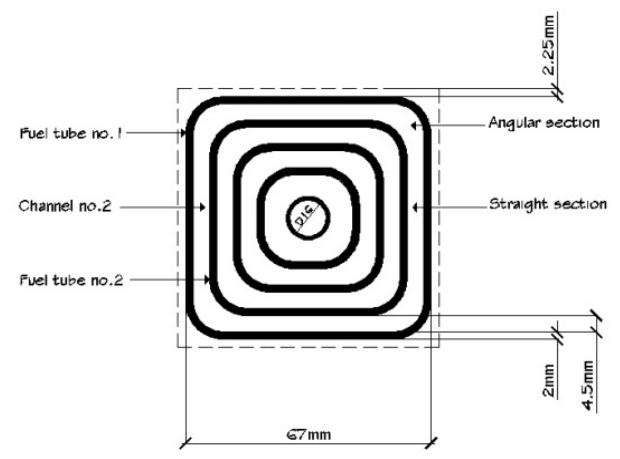

Figure 2. Four-tube fuel assembly

\subsection{Heat flux distribution}

The heat characteristics of the core are found from thermal neutron flux measurements, (neutrons $/ \mathrm{cm}^{2} \cdot \mathrm{s}$ ) in the water channels of FAs and the fuel burn-up data $b$ (dimensionless), where heat flux $\mathrm{q}\left(\mathrm{kW} / \mathrm{m}^{2}\right)$ is proportional to (1-b). Due to core symmetry, one quarter of FAs is considered, namely: FAs 5-1, 6-1, 5-2, 6-2, 7-2, 6-3 and 7-3, see figure 1 . The distribution of heat flux in the core can be expressed in terms of three factors. The radial distribution factor $\mathrm{fR}$ for the hot $\mathrm{FA}$ is defined as:

$$
f_{R}=\frac{q_{a}(\text { hot } F A)}{q_{a}(\text { core })}=\frac{q_{a f}}{q_{a c}}
$$

where, subscripts $a, c$ and $f$ refer to average, core and hot FA respectively. According to experimental heat flux distribution [10]; FA6-3 was found to have the maximum average heat flux in the core, i.e. it is the hottest FA with $f_{R}$ equal to 1.418 . The average heat flux in the core is found as:

$$
q_{a c}=\frac{P_{t h} \cdot F_{G}}{A_{c}}
$$

where, $P_{\text {th }}$ is the thermal power of reactor $(5000 \mathrm{~kW}$ at normal operating condition), $A_{c}$ is the heat transfer area of the core, $21.108 \mathrm{~m}^{2}$ and $F_{G}$ is the fraction of thermal power generated within the core, 0.95 [11].

To determine the hot water channel of the six channels within FA6-3, a second factor is defined as the ratio of average heat flux in the hot channel, $q_{a h}$ to that of the FA, $q_{a f}$. It is called microscopic distribution factor $f_{I}$, thus:

$$
f_{I}=\frac{q_{a h}}{q_{a f}}
$$

Where, subscript $h$ refers to hot channel. It is found that water channel no.2, see figure 2 , has the highest value of $f_{I}$ equal to 1.281 [10]. Thus, this channel will be considered later in the hot-spot calculations.

The third factor is the axial distribution factor $f_{z}$ for the hot FA and defined as:

$$
f_{z}=\frac{q_{m}}{q_{a h}}
$$


where, subscript $m$ refers to maximum. The value of $f_{Z}$ for FA6-3 was found to be 1.228 [10]. The variation of local-to-average heat flux $F(z)$ along the hot water channel is shown in figure 3 [10]:

$$
F(z)=\frac{q_{s}(z)}{q_{a h}}
$$

where, subscript $s$ refers to local point and $z$ is the distance from core inlet as percentage of channel length (normalized distance). Obviously, the maximum value of $F(z)$ is $f_{Z}$ which is found at $68 \%$ from inlet.

The radial, microscopic and axial distribution factors were also calculated using a specialized computer code which gave $1.440,1.310$ and 1.245 respectively [10]. It can be noticed that theoretical values are somewhat higher but close to experimental results.

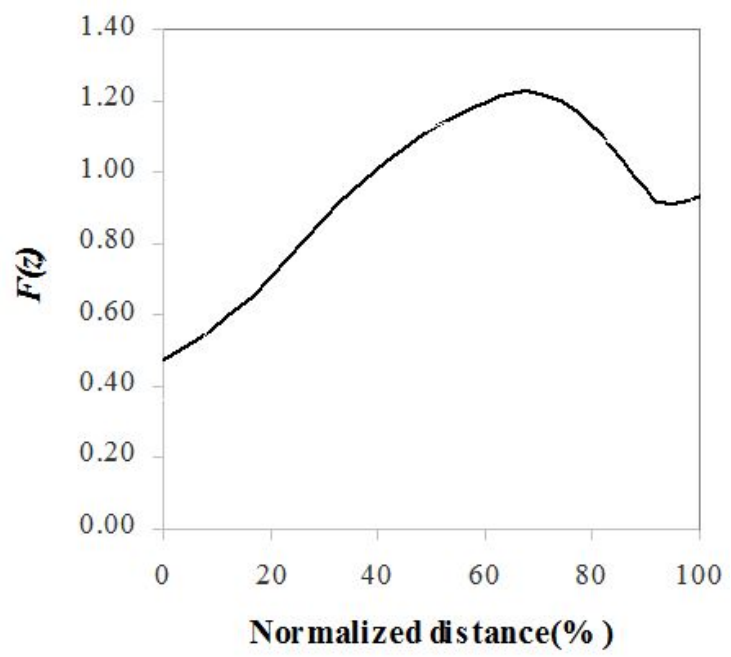

Figure 3. Axial heat flux distribution in the hot channel with normalized distance

\subsection{Coolant flow characteristics}

Water coolant flows in between the fuel tubes, called water channels, from top to bottom of the core via primary circuit pumps. A water channel consists of four straight sections and four angular sections except the central channel which is circular and without fuel tube.

Water velocity in the channels of FAs was measured for unheated core at the nominal pressure drop of 750 $\mathrm{mm}$ water. For the hot channel no.2 of FA6-3, water velocity in straight and angular sections was $1.672 \mathrm{~m} / \mathrm{s}$ and $2.064 \mathrm{~m} / \mathrm{s}$ respectively [12]. These measurements are referred to nominal unheated-channel water velocity, $V_{u c}$. The effect of clad heating during reactor operation on water velocity should be calculated as:

$$
V_{h c}=V_{u c} . F_{v}
$$

where, $V_{h c}$ is the heated-channel water velocity. The factor $F_{v}$ is found using the following two empirical equations [11]:

$$
\begin{gathered}
F_{v}=\left(0.58+0.42 Y_{h}\right)^{-0.5} \\
Y_{h}=1-\left(4.7 \times 10^{-3}-3.3 \times 10^{-5} T_{W}\right) \cdot\left(T_{C}-T_{W}\right)
\end{gathered}
$$

where $T_{W}$ and $T_{C}$ are coolant and clad temperatures $\left({ }^{\circ} \mathrm{C}\right)$ respectively.
For the purpose of temperature calculations, the hot channel no. 2 is divided into two parts according to their corresponding heating surfaces of tube no. 1 and tube no.2, see figure 2 . The values of characteristic parameters of the hot channel as given in table 1 are calculated for the part that corresponds to fuel tube no.1 as the heating surface [11]. Note that flow area $A_{h}$ and equivalent diameter $D_{e}$ are proportional to channel width $\delta$, while heating surface area $A_{T}$ is proportional to length of channel $L$. Finally, the profile of coolant heating is shown in figure 4 as the fraction of heat added $F_{h}(z)$ from inlet to point $z$ in the hot channel of the total heat added in the channel [10].

Table 1. Characteristic parameters of the hot channel

\begin{tabular}{|c|c|c|}
\hline \multirow{2}{*}{ Parameter } & \multicolumn{2}{|c|}{ Nominal value } \\
\cline { 2 - 3 } & straight section & angular section \\
\hline$L(\mathrm{~m})$ & 0.605 & 0.605 \\
\hline$\delta(\mathrm{m})$ & $4.5 \times 10^{-3}$ & $6.0 \times 10^{-3}$ \\
\hline$A_{h}\left(\mathrm{~m}^{2}\right)$ & $105.75 \times 10^{-6}$ & $37.70 \times 10^{-6}$ \\
\hline$A_{T}\left(\mathrm{~m}^{2}\right)$ & $28.435 \times 10^{-3}$ & $7.603 \times 10^{-3}$ \\
\hline$D_{e}(\mathrm{~m})$ & $9.0 \times 10^{-3}$ & $12 \times 10^{-3}$ \\
\hline
\end{tabular}

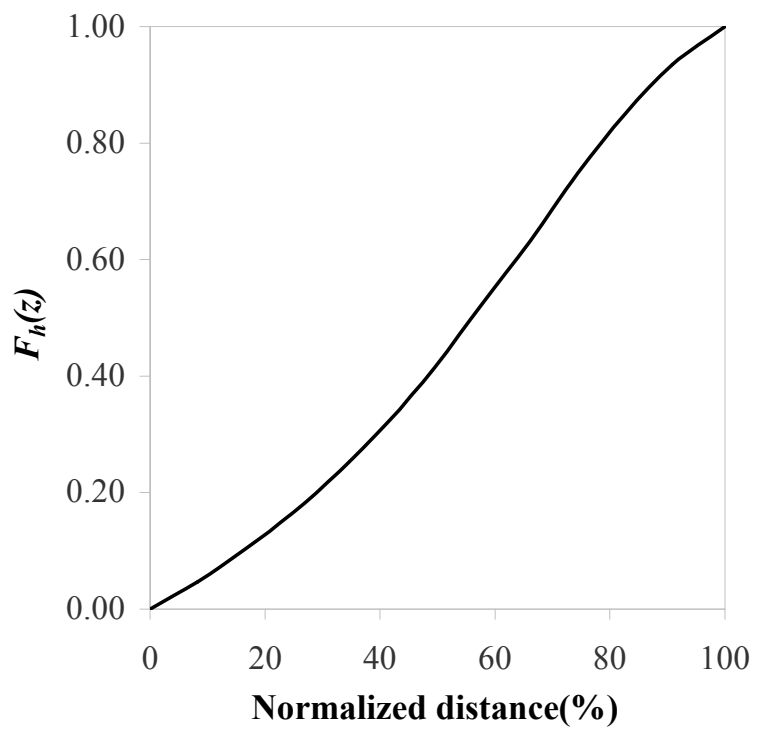

Figure 4. Fraction of heat added in the hot channel with normalized distance

\section{HOT-SPOT CALCULATIONS}

NB is initiated at a position $z$ on clad surface when its temperature $T_{C}$ reaches the nucleate-boiling temperature $T_{B}$ of the coolant. According to this physical interpretation, a well-defined temperature function is used in this paper for the NBSM rather than the common heat flux or power function. This temperature function is given by [11]:

$$
\operatorname{NBSM}(z)=\frac{T_{B}(z)-T_{i}}{T_{C}(z)-T_{i}}
$$

were, subscript $i$ refers to core inlet. Values of $N B S M$ can be expressed as a factor (dimensionless) or as a percentage of the factor above unity $(\%)$. Thus, thermalhydraulic calculations are to be carried out to find the hotchannel temperatures: coolant, clad and nucleate-boiling 
as functions of position $z$ in the hot channel. The particular position that corresponds to some minimum value of $N B S M$ is called hot-spot. Then, iterative procedure is applied to locate such hot-spot position in the hot channel.

For the case of normal operating condition, the minimum obtained value of NBSM will be assigned for the core. In the second case, for a given coolant velocity within a certain range of flow variation the corresponding, reactor thermal power $P_{t h}$ is to be determined such that a minimum value of unity (zero\%) is observed for the NBSM. Nominal, cumulative and statistical analysis will be adopted in the hot-spot calculations for the two cases as explained in the following subsections.

\subsection{Nominal analysis}

In this approach, it is assumed that there is no deviation in design and operating parameters of the core including measurements and fabrication works, i.e. all core conditions are fixed at their nominal values. The hotchannel temperatures at position $z$ are calculated based on energy balance along the hot channel [13]. Accordingly, coolant temperature $T_{W}$ is found first from enthalpy rise from inlet to point $z$ as:

$$
h(z)=h_{i}+\frac{Q(z)}{\dot{m}}
$$

where, $h$ is the corresponding coolant enthalpy $(\mathrm{kJ} / \mathrm{kg})$. The mass flow rate $\dot{m}(\mathrm{~kg} / \mathrm{s})$ is given by:

$$
\dot{m}=V_{h c} \cdot \rho \cdot A_{h}
$$

where, $\rho$ is the coolant density $\left(\mathrm{kg} / \mathrm{m}^{3}\right)$. The heat added $Q(z)(\mathrm{kW})$ from inlet to position $z$ in the hot channel is:

$$
Q(z)=q_{a h} \cdot A_{T} \cdot F_{h}(z)
$$

The average heat flux in the hot channel $q_{a h}\left(\mathrm{~kW} / \mathrm{m}^{2}\right)$ is found as:

$$
q_{a h}=q_{a c} \cdot f_{R} \cdot f_{I}
$$

Then, clad temperature $\left({ }^{\circ} \mathrm{C}\right)$ is calculated as:

$$
T_{C}(z)=T_{W}(z)+\frac{q_{S}(z)}{H}
$$

where, $T_{W}(z)$ is the coolant temperature $\left({ }^{\circ} \mathrm{C}\right)$ which is found from the corresponding enthalpy $h(z)$ from (10). The local heat flux $q_{s}(z)\left(\mathrm{kW} / \mathrm{m}^{2}\right)$ is given by:

$$
q_{S}(z)=q_{a h} \cdot F(z)
$$

The heat transfer coefficient, $H\left(\mathrm{~kW} / \mathrm{m}^{2} .{ }^{\circ} \mathrm{C}\right)$, between cladding and coolant is calculated using the following empirical correlation [11] which includes the effect of additional turbulence at core inlet:

$$
H=2.226 \times 10^{-5} \frac{K_{W}}{D_{e}} \operatorname{Re}^{0.8} \operatorname{Pr}^{0.68} \operatorname{Pr}_{c}{ }^{-025}
$$

where, $K_{W}$ is coolant thermal conductivity $\left(\mathrm{W} / \mathrm{m} .{ }^{\circ} \mathrm{C}\right), R e$ is Reynolds number, $\operatorname{Pr}$ is Prandtle number at coolant temperature and $P r_{c}$ is Prandtle number at clad temperature.
The third hot-channel temperature is the nucleateboiling temperature $\left({ }^{\circ} \mathrm{C}\right)$ at onset situation which is found using the empirical correlation [11]:

$$
T_{B}(z)=T_{S}(z)+2.03\left(q_{S}(z)\right)^{0.35} \cdot\left(P_{S}(z)\right)^{-0.23}
$$

where, $T_{S}$ is the coolant saturation temperature $\left({ }^{\circ} \mathrm{C}\right)$ at the local pressure $P_{s}$ (bar). The coolant pressure at position $z$ in the hot channel is found as [14]:

$$
\begin{aligned}
P_{S}(z)=P_{a t m}+10^{-5}\left[\rho g\left(z_{o}+z\right)\right]- \\
{\left[P_{e}+\frac{1}{2} \rho V_{h c}^{2}\left(1+f_{c} \frac{z}{D_{e}}\right) 10^{-5}\right] }
\end{aligned}
$$

The first two terms together represents the coolant static pressure, where $P_{a t m}$ is the atmospheric pressure, $z_{o}$ is water level above the core $(6 \mathrm{~m})$ and $g$ is the gravity constant. The entrance pressure loss $P_{e}$ was found to be $27 \%$ of the core pressure drop [12]. The last two terms are dynamic and friction pressure losses respectively, where the friction coefficient $f_{C}$ is given by [11]:

$$
f_{c}=0.316 R e^{-0.25}
$$

Finally, NBSM is found by applying (9). Special correlations where developed in this work using available data $[15,16]$ for the different water properties with operating temperatures as needed for the thermalhydraulic calculations.

\subsection{Cumulative analysis}

In a real core, various uncertainties exist in the operating conditions, dimensions, correlations and other parameters. For conservative hot-spot analysis, such uncertainties should be taken into consideration. When all of the worst values of uncertainties are assumed to occur simultaneously in the hot channel, then this approach is called cumulative analysis $[1,2,4]$.

According to IRT-5000 data [11], there are eleven sources of such uncertainties as given in table 2 . The quantitative effect, called hot-channel factor, of each uncertainty on core parameters is found by inspection. Except two hot-channel factors, for a given uncertainty $u$, the corresponding factor is $1-u$. The velocity factor for pressure drop uncertainty is $(1-u 10)^{0.5}$ since velocity is proportional to square root of pressure drop. For channel width uncertainty, the associated velocity factor is determined from relation of velocity with channel width. This relation can be derived using the term of friction pressure loss from (18). For constant core pressure drop, velocity is found to be proportional to (channel width) $^{0.7143}$. Thus, velocity factor for channel width uncertainty is $(1-u 9)^{0.7143}$.

Table 2 shows the values of hot-channel factors for the uncertainties of IRT-5000 core with superscripts $(*)$ for straight section and (**) for angular section of the hot-channel.

The hot-spot calculations for cumulative analysis are performed using the same procedure of previous subsection however with the values of core parameters are to be multiplied by their corresponding hot-channel factors of table 2. Clearly, for zero uncertainties, i.e. unity hot-channel factors, nominal analysis is obtained. 
Table 2. Hot-channel factors for the different uncertainties

\begin{tabular}{|c|c|c|c|c|c|c|c|c|c|c|c|c|c|}
\hline \multicolumn{2}{|c|}{ Sources of the uncertainty } & $u \%$ & $P_{t h}$ & $q_{a h}$ & $f_{R}$ & $f_{I}$ & $F(z)$ & $q_{s}$ & $H$ & $A_{T}$ & $A_{h}$ & $D_{e}$ & $V_{h c}$ \\
\hline$u 1$ & $\begin{array}{l}\text { Measurement accuracy } \\
\text { of thermal power }\end{array}$ & -4 & 1.04 & & & & & & & & & & \\
\hline$u 2$ & $\begin{array}{l}\text { Tolerance of fuel } \\
\text { weight in hot tube }\end{array}$ & -6.8 & & 1.068 & & & & & & & & & \\
\hline$u 3$ & $\begin{array}{l}\text { Experimental deviation } \\
\text { of radial heat flux } \\
\text { distribution factor }\end{array}$ & -2 & & & 1.02 & & & & & & & & \\
\hline$u 4$ & $\begin{array}{l}\text { Experimental deviation } \\
\text { of microscopic heat flux } \\
\text { distribution factor }\end{array}$ & -2 & & & & 1.02 & & & & & & & \\
\hline 45 & $\begin{array}{l}\text { Experimental deviation } \\
\text { of axial heat flux } \\
\text { distribution factor }\end{array}$ & -2 & & & & & 1.02 & & & & & & \\
\hline$u 6$ & $\begin{array}{l}\text { Tolerance of local fuel } \\
\text { distribution in hot tube }\end{array}$ & -15 & & & & & & 1.15 & & & & & \\
\hline$u 7$ & $\begin{array}{l}\text { Correlation deviation of } \\
\text { heat transfer coefficient }\end{array}$ & +15 & & & & & & & 0.85 & & & & \\
\hline 48 & $\begin{array}{l}\text { Tolerance of fuel tube } \\
\text { length }\end{array}$ & -3.31 & & & & & & & & 1.033 & & & \\
\hline 49 & $\begin{array}{l}\text { Tolerance of water } \\
\text { channel width }\end{array}$ & $\frac{+4.44 *}{+3.33^{* *}}$ & & & & & & & & & $\frac{0.956^{*}}{0.967^{* *}}$ & $\frac{0.956^{*}}{0.967^{* *}}$ & $\frac{0.968^{*}}{0.976^{* *}}$ \\
\hline u10 & $\begin{array}{l}\text { Measurement accuracy } \\
\text { of core pressure drop }\end{array}$ & +2 & & & & & & & & & & & 0.99 \\
\hline$u 11$ & $\begin{array}{l}\text { Measurement accuracy } \\
\text { of coolant velocity }\end{array}$ & +11 & & & & & & & & & & & 0.89 \\
\hline
\end{tabular}

\subsection{Statistical analysis}

From statistical point of view, the probability that extreme values of all uncertainties occurring at the same fuel tube in the core, as assumed in the cumulative approach, is quite rare. A more realistic approach is to combine uncertainties in a statistical rather than multiplicative manner [1,2 and 4]. In such approach, an uncertainty is considered to be normally distributed with one-sided confidence limit $99.865 \%$ which equivalent to three standard deviations [17]. Thus, NBSM would be lower than the statistically calculated figure in 1.35 fuel tube out of 1000, knowing that there are 104 fuel tubes in the IRT-5000 core.

The fully-statistical method is used in this paper where all uncertainties are assumed to be statistical $[1,4]$. Accordingly, statistical hot-spot calculations are based on the combination of nominal analysis results for coolant temperature, clad temperature and local heat flux and their corresponding deviations due to different uncertainties as follows:

$$
\begin{gathered}
\left(T_{W}\right)_{s t}=\left(T_{W}\right)_{n o m}+\sqrt{\sum\left(d_{W} \cdot \Delta T_{W}\right)^{2}} \\
\left(T_{C}\right)_{s t}=\left(T_{C}\right)_{n o m}+\sqrt{\sum\left(d_{W} \cdot \Delta T_{W}+d_{C} \cdot \Delta T_{C}\right)^{2}} \\
\left(q_{s}\right)_{s t}=\left(q_{s}\right)_{\text {nom }}+\sqrt{\sum\left(d_{q} \cdot q_{s}\right)^{2}} \\
\left(T_{B}\right)_{s t}=\left(T_{S}\right)_{\text {nom }}+2.03\left(q_{S}\right)_{s t}^{0.35} \cdot\left(P_{s}\right)_{\text {nom }}^{-0.23}
\end{gathered}
$$

Where: subscripts nom and st refer to nominal and statistical values respectively. $\Delta T_{W}$ is the nominal hotspot bulk temperature rise $=T_{W}-T_{i}$ and $\Delta T_{C}$ is the nominal hot-spot film temperature rise $=T_{C}-T_{W}$. The $d_{W}, d_{C}$ and $d_{q}$ are the deviations in coolant temperature, clad temperature and local heat flux respectively.
For an uncertainty $u$, the corresponding deviation $d$ is $|u|$ except for the uncertainties $u 7, u 9, u 10$ and $u 11$. The $u 7$ of heat transfer coefficient affects clad temperature only. The film temperature rise is proportional to ( c) $1 / H$, then the deviation $d_{C}$ is $\left[(1-u 7)^{-1}-1\right]$. Considering the $u 9$ of channel width, bulk temperature rise is $\propto 1 /\left(V_{h c} A_{h}\right)$ and $V_{h c}$ is $\propto A_{h}{ }^{0.7143}$, then the deviation $d_{W}$ is [(1-u9 $\left.)^{-1.7143}-1\right]$. Also, due to $u 9$, film temperature rise is $\propto D_{e}^{0.2} / V_{h c}{ }^{0.8}$ then the deviation $d_{C}$ is $\left[(1-u 9)^{-0.3714}-1\right]$.

For the $u 10$ of core pressure drop, bulk temperature rise is $\propto 1 / V_{h c}$, where $V_{h c}$ is $\propto$ square root of core pressure drop, then the deviation $d_{W}$ is $\left[(1-\mathrm{u} 10)^{-0.5}-1\right]$, while film temperature rise is $\propto 1 / V_{h c} 0.8$, then the deviation $d_{C}$ is $\left[(1-u 10)^{-0.4}-1\right]$. Similarly, for the $u 11$ of coolant velocity the deviation $d_{W}$ is $\left[(1-u 11)^{-1}-1\right]$ and the deviation $d_{C}$ is $\left[(1-u 11)^{-0.8}-1\right]$.

The calculated values of deviations in table 3 are to be used in $(20-23)$ to find the NBSM for the statistical approach.

\section{RESULTS AND DISCUSSION}

Applying the three different analyses as nominal, cumulative and statistical for the IRT-5000 research reactor, thermal-hydraulic hot-spot calculations were carried out with the maximum coolant inlet temperature $T_{i}$ of $45^{\circ} \mathrm{C}$.

A computer simulation program is developed for that purpose which gave the following results.

The hot-spot position $z$ is found to be in the range of $69 \%$ for the angular section to $74 \%$ for the straight section of the hot channel which is beyond the position of maximum heat flux at $68 \%$. The effect of clad heating on coolant velocity was (2-4) \% which provides an equal amount of operating margin for heat flux and reactor thermal power. Coolant pressure at hot-spot was (1.53-1.59) bar which indicates low sensitivity to both 
operating conditions and method of calculation. This justifies the use of nominal coolant saturation temperature for the different hot-spot calculations in the present paper. The thermal-hydraulic analyses showed that the straight section of the hot channel is the hottest section. In addition, simulation results indicated that local fuel distribution uncertainty $(u \sigma)$ has a major contribution for the reduction in NBSM due to its larger effect on both local heat flux and clad temperature at hot-spot. Moreover, a very important result is that statistical NBSMs were found to be at the mid-point between the two extremes of nominal and cumulative values such as:

$$
(N B S M)_{s t}=\frac{(N B S M)_{n o m}+(N B S M)_{c u m}}{2}
$$

The whole results of the present work are discussed with details in the following subsections.

Table 3. Deviations of hot-spot bulk and film temperature rises and local heat flux for the different uncertainties

\begin{tabular}{|c|c|c|c|}
\hline Uncertainty & $\begin{array}{c}\text { Bulk } \\
\text { temperature } \\
\text { rise } \\
\text { deviation } \\
d_{W}\end{array}$ & $\begin{array}{c}\text { Film } \\
\text { temperature } \\
\text { rise } \\
\text { deviation } d_{C}\end{array}$ & $\begin{array}{c}\text { Local heat } \\
\text { flux } \\
\text { deviation } \\
d_{q}\end{array}$ \\
\hline$u 1$ & 0.04 & 0.04 & 0.04 \\
$u 2$ & 0.068 & 0.068 & 0.068 \\
$u 3$ & 0.02 & 0.02 & 0.02 \\
$u 4$ & 0.02 & 0.02 & 0.02 \\
$u 5$ & 0 & 0.02 & 0.02 \\
$u 6$ & 0 & 0.15 & 0.15 \\
$u 7$ & 0 & 0.1765 & 0 \\
$u 8$ & 0.0331 & 0 & 0 \\
$u 9$ & $\underline{0.081^{*}}$ & $\underline{0.017^{*}}$ & 0 \\
$u 10$ & $0.06^{* *}$ & $0.013^{* *}$ & 0 \\
$u 11$ & 0.01 & 0.0081 & 0 \\
\hline
\end{tabular}

\subsection{Case 1: normal operating condition}

For reactor thermal power $5 \mathrm{MW}$ and nominal coolant velocity $1.672 \mathrm{~m} / \mathrm{s}$ and $2.064 \mathrm{~m} / \mathrm{s}$ in straight and angular sections respectively, the hot-spot results of the three different analyses are shown in table 4 which includes local heat flux $q_{s}$, coolant temperature $T_{W}$, clad temperature $T_{C}$, coolant saturation temperature $T_{S}$, nucleateboiling temperature $T_{B}$ and NBSM for both sections of the hot channel.

The NBSM for the hottest section was $59 \%, 2.3 \%$ and $30.8 \%$ with nominal, cumulative and statistical analysis respectively. Higher NBSM values were found for the angular section. The straight section was of bulk and film temperature rise $\left({ }^{\circ} \mathrm{C}\right)$ with nominal, cumulative and statistical analysis: 11.3 and 41.6, 16.1, and 67.9, and 13.3 and 51.7 respectively; while angular section was of lower values. Nucleate-boiling temperature was higher than saturation temperature of the coolant by about $17{ }^{\circ} \mathrm{C}$. The nominal values of average and maximum heat flux in the core were $225 \mathrm{~kW} / \mathrm{m}^{2}$ and 502 $\mathrm{kW} / \mathrm{m}^{2}$ respectively.

\subsection{Case 2: coolant flow variation}

In this case, coolant velocity in the hottest section of channel no.2 is varied around its nominal value in the range of $(1.2-2.2) \mathrm{m} / \mathrm{s}$ and the corresponding reactor thermal power is found using each of the three hot-spot analyses such that zero\% NBSM is obtained. Such relation of reactor power with coolant velocity is drawn in figure 5. This figure shows that reactor power limit is 9.04 MW, 5.13 MW and 7.05 MW according to nominal, cumulative and statistical analysis respectively at normal coolant velocity. It can be noticed that using power ratio, the corresponding $N B S M$ will be $81 \%$ and $41 \%$ for nominal and statistical analysis respectively which are overestimates as compared to those using the temperature function of (9).

During transients of reactor trip conditions for power increase $(120 \%$ of nominal value) and coolant flow decrease $(80 \%$ of nominal value), the nominal analysis indicated that NB will not occur even when both trip conditions are happened simultaneously. However, according to cumulative analysis, NB will be initiated during any of the two trip transients. While, statistical analysis showed that no NB will be observed when only one of the two trip conditions is encountered. Note that such transient NB might occur for only short period during reactor shutdown so it has no serious effect as the steady-state NB during normal reactor operation.

\subsection{Comparative evaluation of NBSMs}

Figure 5 has drawn the set of operating conditions for constant NBSM (here zero\%). Such a set can be defined as an operating state specified by a number $n$ that is linearly proportional to nominal NBSM. By changing reactor power and coolant velocity, different operating states can be collected such that a relation between $N B S M$ and operating state $n$ is obtained for each hotspot analysis as shown in figure 6 .

Higher operating states correspond to better operating conditions of lower power and/or higher coolant velocity. The vertical line in figure 6 at state no. 6 represents the normal operating condition of the reactor. By examining and comparing the corresponding equations for $N B S M$ with operating state $n$, a strong linear correlation among the different thermal-hydraulic hotspot analyses can be observed.

Table 4. Hot-spot results for the normal operating condition

\begin{tabular}{|c|c|c|c|c|c|c|}
\hline \multirow{2}{*}{ Parameter } & \multicolumn{2}{|c|}{ Nominal analysis } & \multicolumn{2}{c|}{ Cumulative analysis } & \multicolumn{2}{c|}{ Statistical analysis } \\
\cline { 2 - 7 } & straight section & angular section & straight section & angular section & straight section & angular section \\
\hline $\boldsymbol{q}_{\boldsymbol{s}}\left(\mathbf{k W} / \mathbf{m}^{2}\right)$ & 493.4 & 498.5 & 671.4 & 679.0 & 578.8 & 584.7 \\
\hline $\boldsymbol{T}_{\boldsymbol{W}}\left({ }^{\circ} \mathbf{C}\right)$ & 56.3 & 51.5 & 61.1 & 53.9 & 58.3 & 52.6 \\
\hline $\boldsymbol{T}_{\boldsymbol{C}}\left({ }^{\circ} \mathbf{C}\right)$ & 97.9 & 90.3 & 129.0 & 117.6 & 110.0 & 101.2 \\
\hline $\boldsymbol{T}_{\boldsymbol{S}}\left({ }^{\circ} \mathbf{C}\right)$ & 113.1 & 112.9 & 113.1 & 112.9 & 113.1 & 112.9 \\
\hline $\boldsymbol{T}_{\boldsymbol{B}}\left({ }^{\circ} \mathbf{C}\right)$ & 129.1 & 129.0 & 130.9 & 130.8 & 130.0 & 129.9 \\
\hline $\boldsymbol{N B S M}$ & 1.59 & 1.85 & 1.02 & 1.18 & 1.31 & 1.51 \\
\hline
\end{tabular}




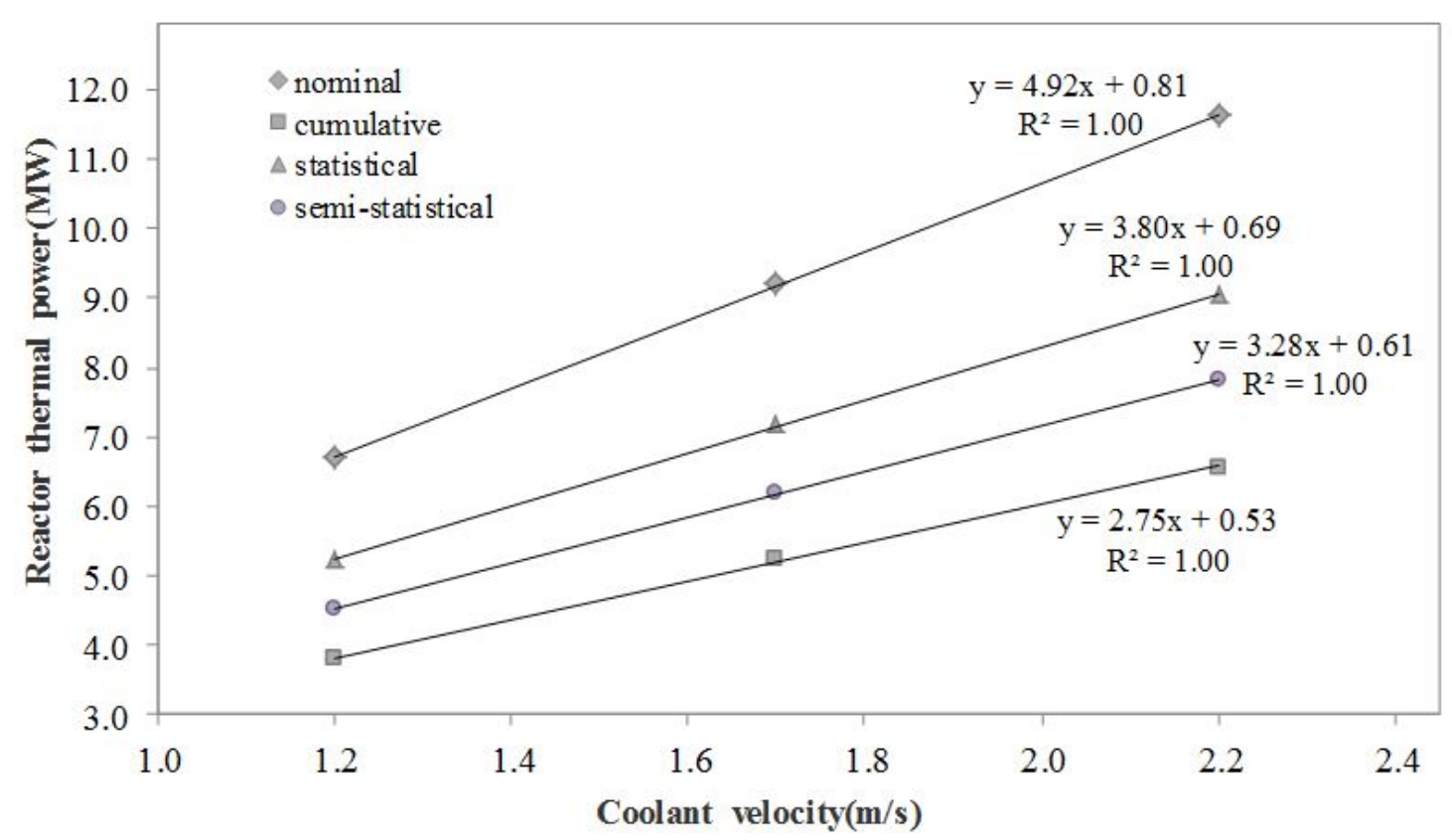

Figure 5. Reactor power with coolant velocity for zero\% NBSM

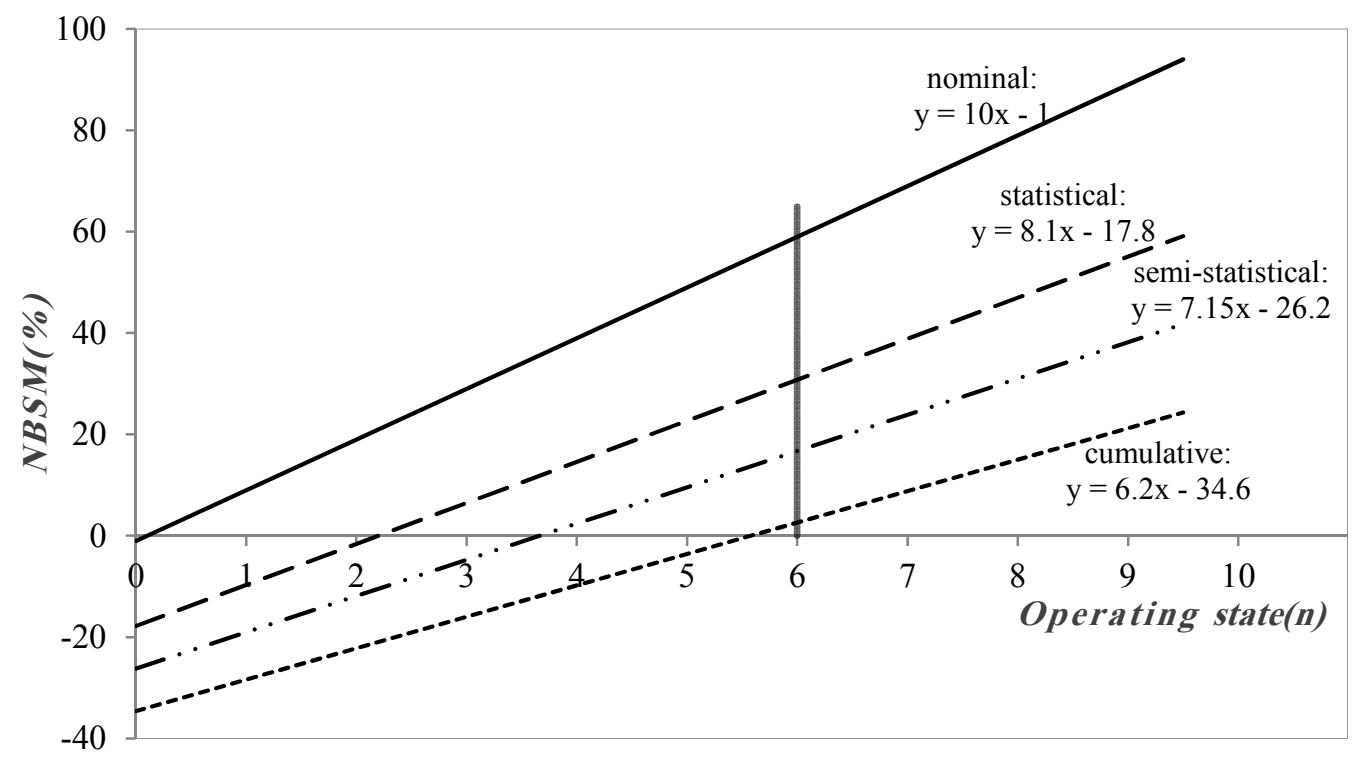

Figure 6. NBSM with operating state for different hot-spot analyses

This relative relation indicates a new significant result that, for a known operating state or condition, the various NBSMS are actually uniquely quantified. Furthermore, the semi-statistical hot-spot analysis can be argued to be at mid-point between that of cumulative and statistical values of figures 5 and 6 .

Accordingly, IRT-5000 reactor at the normal operating condition will have a semi-statistical NBSM of $16.7 \%$ with power limit $6.08 \mathrm{MW}$. In fact, the new comparative relationship among nominal, cumulative, statistical and semi-statistical hot-spot analyses can also be verified using the results of Khalil et al. [1] and Chiang [2].

\section{CONCLUSION}

In this paper, thermal-hydraulic hot-spot analyses were performed for normal and transient operating conditions of the IRT-5000 nuclear research reactor to evaluate the safety margins to NB phenomenon. For that purpose, a computer simulation program was developed with three different approaches for the hot-spot calculations: nominal, cumulative and statistical, using experimental core data including heat flux factors, coolant heating profile, velocity distribution, hot-channel uncertainties, nucleate-boiling and heat transfer correlations. Comparative investigation of the different NBSM results was carried out for relative interrelation. To the best knowledge of the authors, no previously published paper was found for such thermal-hydraulic safety analyses of the IRT-5000 reactor. On the basis of the present work, the following findings and conclusions have been drawn:

- The systematic methodology presented in this paper for NBSM can be adopted as a safety analysis for other research reactors.

- The well-defined temperature function introduced in this paper for the NBSM is more realistic than the commonly used heat flux or power ratio. 
- Safe reactor operation with respect to NB is assured during normal operating condition. According to the pessimistic calculations of cumulative analysis, the safety margin was $2.3 \%$ with reactor power limit 5.13 MW; however transient NB would be initiated during reactor trip condition.

- Among the eleven core uncertainties, local fuel distribution uncertainty (u6) has a great negative effect on NBSM. However, this effect can be reduced by appropriate relocation of fuel assemblies in the core according to fuel certificate data.

- At constant NBSM, the reactor thermal power is linearly proportional to coolant velocity, i.e. constant slopes of power-velocity lines. The smallest slope is obtained with the cumulative analysis. On the other hand, lines of higher NBSM are found to be of smaller slopes.

- The comparative evaluation indicates a very important finding that the different hot-spot analyses are strongly correlated. For an operating condition of known NBSM according to one analysis, the corresponding NBSMs of the other analyses would be directly specified without the need for further calculations.

\section{ACKNOWLEDGMENT}

IRT-5000 documents used in this paper, references 10 , 11 and 12, were issued by the former Iraqi Atomic Energy Commission (IAEC).

\section{REFERENCES}

[1] Khalil, M.Y., Abdelrazek, I.D., Nagy, M.E. and Shokr, A.M.: Hot channel factors evaluation for thermalhydraulic analysis of MTR reactors, Nukleonika, Vol. 49, No. 2, pp. 61-67, 2004.

[2] Chiang, K.Y.: Thermal Hydraulic Limits Analysis for the MIT Research Reactor Low Enrichment Uranium Core Conversion Using Statistical Propagation of Parametric Uncertainties, M.Sc. thesis, MIT, June 2012.

[3] Ardaneh, K. and Zaferanlouei, S.: An analytical solution for thermal-hydraulic analysis and safety margins in MTR-type research reactors cooled by natural convection, Annals of Nuclear Energy, Vol. 51, pp. 282-288, 2013.

[4] Farhadi, K.: Statistical calculation of hot channel factors, Journal of Nuclear and Radiation Physics, Vol. 3, No. 1, pp. 11-20, 2008.

[5] Al-Yahia, O.S. and Jo, D.: Onset of nucleate boiling for subcooled flow through a one-side heated narrow rectangular channel, Annals of Nuclear Energy, Vol. 109, pp. 30-40, 2017.

[6] Stevanovic, V., Prica, S. and Maslovaric, B.: Multifluid model predictions of gas-liquid two-phase flows in vertical tubes, FME Transactions, Vol. 35, No. 4, pp. 173-181, 2007.

[7] Tucakovic, D., Stevanovic, V. and Zivanovic, T.: Thermal-hydraulics of evaporating tubes in the forced circulation loop of a steam boiler, FME Transactions, Vol. 36, No. 1, pp. 9-19, 2008.
[8] Petrovic, M.M. and Stevanovic, V.D.: Twocomponent two-phase critical flow, FME Transactions, Vol. 44, No. 2, pp. 109-114, 2016.

[9] Fynan, D.A. and Ahn, K.-Il: Implicit treatment of technical specification and thermal hydraulic parameter uncertainties in Gaussian process model to estimate safety margin, Nuclear Engineering and Technology, Vol. 48, pp. 684-701, 2016.

[10]IAEC: Heat Flux and Water Heat-up Distributions of IRT-5000 Core, unclassified report.

[11]IAEC: IRT-5000 Design Specifications, Fabrication Data and Empirical Correlations, unclassified report.

[12]IAEC: Experimental Measurements of Thermal Neutron Flux, Water Velocities and Core Pressure Losses of IRT-5000, unclassified report.

[13] Janna, W.S.: Engineering heat transfer, second edition, CRC Press, Florida, 2000.

[14] White, F.M.: Fluid mechanics, fourth edition, WCB McGraw-Hill, 1998.

[15] Moran, M.J., Shapiro, H.N., Boettner, D.D. and Bailey, M.B.: Fundamentals of engineering thermodynamics, seventh edition, John Wiley and Sons Inc., 2011.

[16] Holman, J.P.: Heat transfer, eighth edition, McGraw-Hill, New York, 1997.

[17] Montgomery, D.C., and Runger, G.C.: Applied statistics and probability for engineers, fifth edition, John Wiley and Sons Inc., 2011.

\section{ТЕРМО-ХИДРАУЛИЧНА ХОТ СПОТ АНАЛИЗА ИСТРАЖИВАЧКОГ НУКЛЕАРНОГ PЕАКТОРА IRT-500: КОМПАРАТИВНА ЕВАЛУАЦИЈА СИГУРНОСТИ}

\section{Х.М.Т. Ал-Наџар, А.В. Ецат}

Рад приказује у појединостима методологију израчунавања коефицијента сигурности кључања језгра код истраживачког нуклеарног реактора, коришћењем функције температуре уз три различите термохидрауличне хот спот анализе као што је номинална, кумулативна и статистичка анализа за нормалне радне услове реактора и варијација у протоку расхладног средства. Развијен је софтвер за симулацију примене методологије на реактору IRT-500 базиран на подацима о језгру. Према кумулативној анализи, као најстаријем конвенционалном приступу коефицијенту сигурности, коефицијент сигурности при нормалним радним условима и снази од $5 \mathrm{MW}$ и брзини расхладносг средства од $1,672 \mathrm{M} / \mathrm{c}$ је износио $2,3 \%$ а гранична снага реактора 5,13 MW. Међутим, код поремећаја протока или снаге може да дође до транзиторног краткотрајног кључања језгра и престанка рада реактора. Када је варирање коефицијента сигурности у условима рада реактора испитано различитим хот-спот анализама утврђено је да су оне у јакој корелацији, тако да је довољно применити једну да би се одредили резултати друге анализе. 
